\title{
Immunophenotyping of acute lymphoblastic leukaemia in routinely processed bone marrow biopsy specimens
}

\author{
B Toth, M Wehrmann, E Kaiserling, H-P Horny
}

\begin{abstract}
Aims-To assess the value of immunophenotyping of acute lymphoblastic leukaemia (ALL) in routinely processed bone marrow trephine biopsy specimens and to establish a minimum panel of antibodies to assess lymphoid lineage and enable differentiation from acute myeloid leukaemia.

Methods-45 routinely processed bone marrow biopsy specimens (formalin fixed, paraffin embedded and mildly decalcified in EDTA) reported to contain leukaemic infiltrates on the basis of cytomorphological and enzyme-cytochemical analysis of bone marrow smears (22 c-ALL, 11 T-ALL, 2 B-ALL, 10 u-ALL (unclassified)) were immunostained by the ABC method with a broad panel of 26 antibodies against various haemopoietic antigens.

Results-Staining with antibodies directed against myeloperoxidase and lysozyme showed that seven cases were either biphenotypic or mixed leukaemias (2), or of myelogenous origin (acute myeloid leukaemia (AML)-M1 (2); AML-M4 (2); AML-M5a (1)). Five of these seven cases had been diagnosed initially as u-ALL. Three further cases with no compact leukaemic infiltrates were excluded. ALL was confirmed in the remaining 35 cases. Because of revised diagnoses, the total numbers of ALL subtypes changed (23
\end{abstract}

Institute of Pathology, University of Tübingen,

Liebermeisterstr 8, D-72076 Tübingen, Germany

B Toth

M Wehrmann

E Kaiserling

H-P Horny

1 June 1999

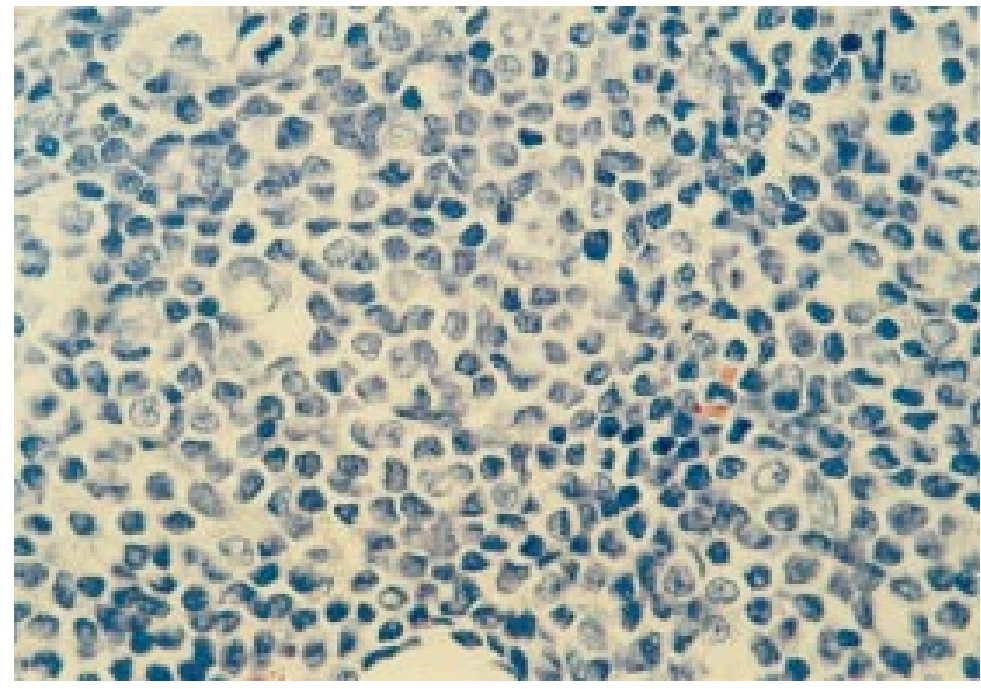

Figure 1 Extremely hypercellular marrow with subtotal depletion of fat cells and blood cell precursors. Diffuse infiltration by small to medium sized blast cells with irregular nuclei and scanty cytoplasm. (Giemsa, $\times 289$.)
c-ALL, 8 T-ALL, 2 B-ALL, 2 u-ALL). Immunostaining of more than $10 \%$ of blast cells in at least one case was found with 19 of the 26 antibodies. The most sensitive lineage specific antibodies for diagnosis were found to be anti-CD10 for c-ALL (22I 23) and $\beta F 1$ for T-ALL (6/8). Expression of aberrant antigens was fairly common-for example, 7/23 cases of c-ALL stained with antibodies against $\mathbf{T}$ cell associated antigens.

Conclusions-Immunohistochemical investigation of routinely processed bone marrow biopsy specimens enables reliable detection of ALL subtypes c-ALL and T-ALL. A minimum panel of antibodies, against TdT, CD34, myeloperoxidase, lysozyme, CD10, CD79a, and CD20, and the antibody $\beta F 1$, is proposed for the immunophenotyping of acute leukaemia. (F Clin Pathol 1999;52:688-692)

Keywords: bone marrow; acute lymphoblastic leukaemia; acute myeloid leukaemia; immunohistochemistry

Immunophenotyping has yielded significant new information on the heterogeneity of acute lymphoblastic leukaemia (ALL) and has provided a solid basis for a reproducible classification system. ${ }^{1}$ The classification of ALL is performed by a combination of cytomorphological, enzyme-cytochemical, and immunocytological techniques. Although the immunohistochemical examination of routinely processed bone marrow biopsy specimens has become an essential part of diagnostic haematopathology, acute leukaemia (unlike malignant lymphoma $)^{2-6}$ has been the subject of relatively few immunohistochemical studies. ${ }^{17-10}$ In most of these studies, a relatively small panel of antibodies was applied or only small numbers of cases were examined. The recent development of antibodies directed against important stem cell and B cell associated antigens (for example, TdT and CD10 $)^{11}{ }^{12}$ that can be used on routinely processed tissue has enabled us to study the value of immunophenotyping of ALL in routinely processed bone marrow biopsy specimens and to establish a panel of antibodies to assess lymphoblastic lineage and exclude the diagnosis of acute myeloid leukaemia.

\section{Methods}

Forty five bone marrow biopsy specimens from patients diagnosed as having ALL on the basis of cytomorphological, enzyme-cytochemical, 
Table 1 Main specificities and sources of the antibodies applied

\begin{tabular}{|c|c|c|c|c|}
\hline Antibody (against) & $C D$ & Staining & Main specificity & Source \\
\hline QBEND10 & 34 & a & Haematopoietic stem cells, endothelial cells & 5 \\
\hline TdT & - & $\mathrm{n}$ & Immature lymphoid precursor cells & 1 \\
\hline $\mathrm{MPO}^{\star}$ & - & $\mathrm{c}$ & Granulocytes & 1 \\
\hline Lysozyme^ & - & $\mathrm{c}$ & Macrophages & 1 \\
\hline HM57 & $79 a$ & $\mathrm{a}$ & $\mathrm{B}$ cells & 1 \\
\hline L26 & 20 & a & $\mathrm{B}$ cells & 1 \\
\hline MB1 & 45RA & a & B cells, subset of $\mathrm{T}$ cells & 3 \\
\hline MB2 & 21 & a & B cells & 3 \\
\hline $4 \mathrm{~KB} 5$ & $45 \mathrm{R}$ & a & B cells & 1 \\
\hline $\mathrm{PD} 7 / 26$ & $45 \mathrm{RB}$ & $\mathrm{a}$ & $\mathrm{B}$ cells & 1 \\
\hline LN1 & w75 & a & B cells of the germinal centre & 3 \\
\hline LN2 & 74 & a & B cells & 3 \\
\hline LN3 & - & a & HLA-DR related & 3 \\
\hline UCHL1 & $45 \mathrm{R} 0$ & a & $\mathrm{T}$ cells & 1 \\
\hline MT1 & 43 & $\mathrm{a}$ & $\mathrm{T}$ cells & 3 \\
\hline MT2 & 45RA & a & B cells, subset of $T$ cells & 3 \\
\hline$\alpha \mathrm{F} 1$ & - & a & $\mathrm{T}$ cells & 2 \\
\hline$\beta F 1$ & - & a & $\mathrm{T}$ cells & 2 \\
\hline CD3 & 3 & a & $\mathrm{T}$ cells & 1 \\
\hline OPD4 & - & a & $\mathrm{T}$ cell subset & 6 \\
\hline CD10 & 10 & a & Human CD10 molecule & 6 \\
\hline $\mathrm{Y} 2 / 51$ & 61 & $\mathrm{c}$ & Megakaryocytes & 1 \\
\hline PG-M1 & $68 \mathrm{R}$ & $\mathrm{c}$ & Macrophages & 1 \\
\hline 124 & - & $\mathrm{a}$ & bcl-2 protein & 1 \\
\hline Leu-7 & 57 & $\mathrm{a}$ & Natural killer cells & 4 \\
\hline MIC2 & 99 & a & p32/33 protein & 1 \\
\hline
\end{tabular}

Sources: 1, Dakopatts, Hamburg, Germany; 2, T-Cell Diagnostics Inc, Cambridge, UK; 3, Biotest, Dreieich, Germany; 4, Becton Dickinson, Heidelberg, Germany; 5, Dianova, Hamburg, Germany; 6, Novocastra, Newcastle upon Tyne, UK.

Staining: a, annular (ie, membrane associated); c, cytoplasmic; n, nuclear

^Polyclonal antibodies; all others monoclonal.

and immunocytological investigation of blood and bone marrow smears were drawn from the archives of the Institute of Pathology, University of Tübingen, Germany. The diagnoses were common ALL (c-ALL) (22), T cell ALL (T-ALL) (11), B cell ALL (B-ALL) (2) and ALL not further classified (u-ALL) (10).

All specimens had been processed routinely by fixation in 5\% neutral buffered formalin, mild decalcification in edetic acid (EDTA) for 12 hours, ${ }^{13}{ }^{14}$ and embedding in paraffin. Serial sections were cut at $4 \mu \mathrm{m}$ and stained with haematoxylin and eosin (H\&E), Giemsa (fig 1), the periodic acid-Schiff reaction (PAS), and the naphthol AS-D chloroacetate esterase reaction (CAE).

Immunostaining was performed by the avidin-biotin-peroxidase complex (ABC) method of Hsu et al, ${ }^{15}$ using the 26 antibodies listed in table 1 . The number of immunoreac-

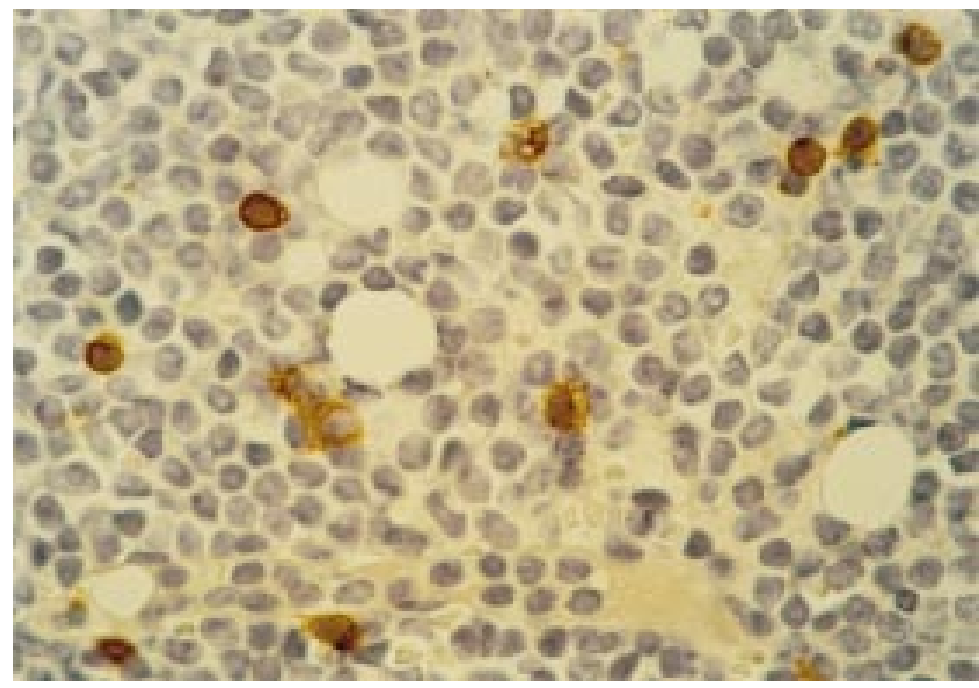

Figure 2 Immunostaining for the $T$ cell associated antigen CD3 reveals loosely scattered lymphoid cells (recorded as “+”). ABC method, anti-CD3; ×289. tive cells was recorded on a four grade scale: 0 , none; + , up to $10 \%$ of nucleated bone marrow cells;,$++ 10-50 \%$ of blast cells; +++ , more than $50 \%$ (usually 100\%) of blast cells (figs $2-4$ ). When only a few of the nucleated bone marrow cells were immunoreactive (less than $10 \%$ ) it was usually impossible to determine whether these were non-neoplastic lymphoreticular cells (histiocytes or T cells) or neoplastic blast cells. Grade "+" was therefore not included in the analysis as "positive" immunostaining. Fisher's exact test, grouping together grades " 0 " and " + " and grades " ++ " and "+++," was used for statistical analysis. Probability values of less than 0.05 were considered significant.

\section{Results}

GENERAL CONSIDERATIONS

In routinely stained sections ( $\mathrm{H} \& \mathrm{E}$, PAS, Giemsa), the bone marrow in almost all cases was found to be extremely hypercellular, with subtotal depletion of fat cells and normal blood cell precursors. Sheets of small to medium sized blast cells with slightly pleomorphic, round to ovoid nuclei, scanty cytoplasm, and only occasional prominent nucleoli dominated the histological picture in most cases. CAE positive blast cells were detected in three cases, in which the diagnosis subsequently proved to be acute myeloid leukaemia (AML-M4 (2); AML-M1 (1)) rather than ALL.

IMMUNOHISTOCHEMICAL FINDINGS

A summary of the immunohistochemical findings is given in tables 2-4. Staining with antibodies against myeloperoxidase (MPO) and lysozyme showed that seven of the 45 cases were biphenotypic or mixed leukaemias (2), or showed clear myeloid differentiation: AML-M1 (2); AML-M4 (2), AML-M5a (1). Three of the specimens in which compact leukaemic infiltrates could not be detected were excluded from further analysis, leaving 35 ALL cases for evaluation.

Nineteen of the 26 antibodies reacted with more than $10 \%$ of the blast cells in at least one case (table 2). The blast cells in each case reacted with at least three and at most 11 of the antibodies applied, and they tended to react with more antibodies in c-ALL than in T-ALL or B-ALL (tables 3 and 4). Twenty three of the cases were classified as c-ALL, eight as T-ALL and two as B-ALL; two could not be classified definitively (u-ALL). By definition, the blast cells of c-ALL showed immunoreactivity for CD10. Most cases of c-ALL also expressed CD43, CD99, CD45RB, TdT, CD79a, and CD34 (tables 3 and 4). The main diagnostic marker was $\beta F 1$ in six of the cases of T-ALL. The blast cells in the two cases of B-ALL expressed the B cell associated antigens CD79a and CD20. The blast cells of four of the seven initially unclassified cases (u-ALL) showed strong immunoreactivity for CD10, thus allowing a diagnosis of c-ALL to be made. In one case, $\beta F 1$ expression led to a diagnosis of T-ALL. The remaining two cases had an inconclusive immunophenotype that did not allow definitive subtyping (table 4 ). 


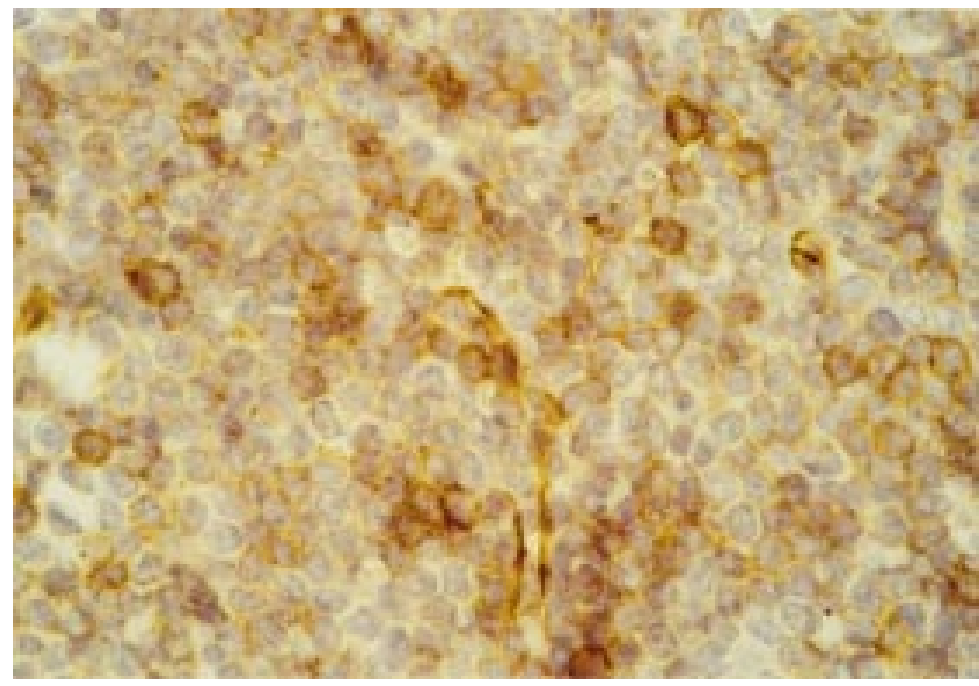

Figure 3 Anti-CD34 produces annular staining of a considerable proportion of the nucleated cells (recorded as "++"). Note that endothelial cells are also reactive. $A B C$ method, anti-CD34 (QBEND 10); ×289.

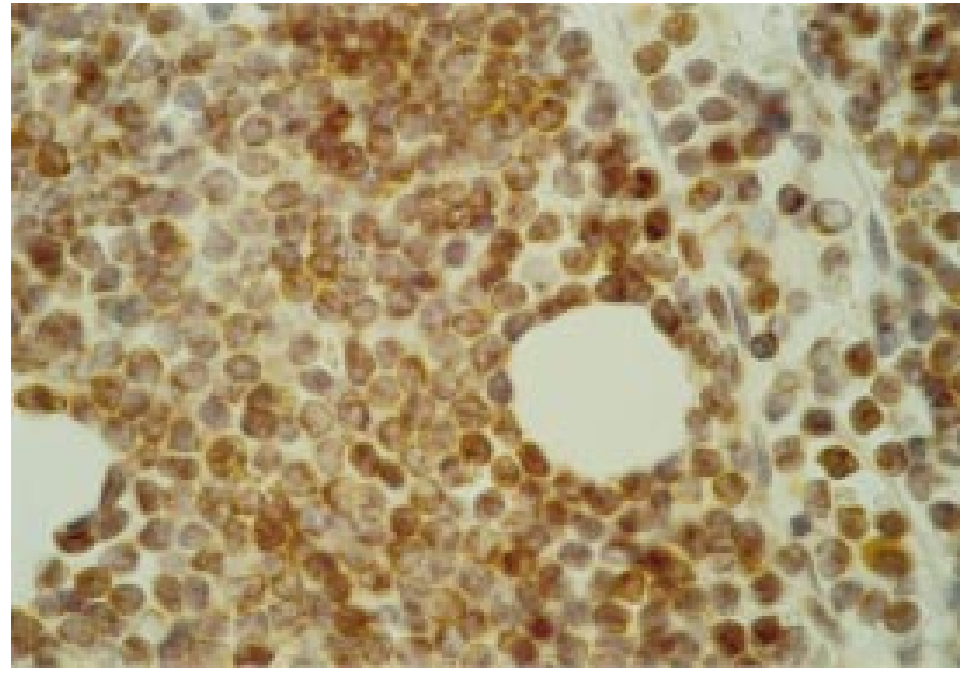

Figure 4 The overwhelming majority of cells (>90\%, recorded as “+++") are reactive for the B cell associated antigen CD79a. Note that endothelial cells are not stained. ABC method, anti-CD79a; $\times 289$.

In summary, the original diagnosis of ALL was confirmed in 38 of the 45 cases (> $80 \%$ ), and it was possible to subtype five of the seven initially unclassified cases of u-ALL.

STATISTICAL FINDINGS

Statistical analysis of the immunohistochemical findings showed that antibodies against the stem cell associated antigens TdT and $\mathrm{CD} 34$ reacted more often with the blast cells of ALL than with those of AML $(\mathrm{p}<0.05)$. CD10 was found to be expressed more often in c-ALL than in T- or B-ALL $(\mathrm{p}<0.05)$.

\section{Discussion}

The main findings of the study were as follows. (1) In most cases the subtyping of ALL into c-ALL and T-ALL can be performed using routinely processed bone marrow trephines if an appropriate panel of antibodies, comprising anti-CD10, anti-CD79a, anti-CD20, and $\beta \mathrm{F} 1$, is applied. (2) ALL can be differentiated from
Table 2 Immunoreactivity of the 35 cases of acute lymphoblastic leukaemia

\begin{tabular}{|c|c|c|c|c|}
\hline \multirow[b]{2}{*}{ Antibody against } & \multicolumn{4}{|c|}{ Immunoreactivity of nucleated cells } \\
\hline & 0 & + & ++ & +++ \\
\hline \multicolumn{5}{|c|}{ Stem cell associated and myelomonocytic antigens } \\
\hline CD34 & 0 & 22 & 1 & 12 \\
\hline TdT & 7 & 3 & 10 & 15 \\
\hline MPO & 2 & 33 & 0 & 0 \\
\hline Lysozyme & 7 & 28 & 0 & 0 \\
\hline CD68R & 0 & 25 & 0 & 0 \\
\hline \multicolumn{5}{|l|}{$B$ cell antigens } \\
\hline CD79a & 15 & 5 & 10 & 5 \\
\hline CD20 & 2 & 24 & 3 & 6 \\
\hline MB1/CD45RA & 2 & 29 & 2 & 2 \\
\hline MT2/CD45RA & 8 & 25 & 2 & 0 \\
\hline $\mathrm{CD} 21$ & 7 & 16 & 11 & 1 \\
\hline CD45R & 12 & 20 & 1 & 2 \\
\hline CD45RB & 0 & 11 & 13 & 11 \\
\hline CDw75 & 25 & 10 & 0 & 0 \\
\hline CD74 & 21 & 14 & 0 & 0 \\
\hline LN3 & 12 & 21 & 1 & 1 \\
\hline \multicolumn{5}{|l|}{$T$ cell antigens } \\
\hline CD10 & 4 & 8 & 7 & 16 \\
\hline CD45R0 & 11 & 17 & 4 & 3 \\
\hline CD43 & 2 & 2 & 3 & 28 \\
\hline$\alpha \mathrm{F} 1$ & 3 & 31 & 1 & 0 \\
\hline$\beta F 1$ & 1 & 24 & 10 & 0 \\
\hline CD3 & 8 & 23 & 3 & 1 \\
\hline OPD4 & 7 & 26 & 2 & 0 \\
\hline \multicolumn{5}{|l|}{ Other antigens } \\
\hline CD99 & 3 & 3 & 4 & 25 \\
\hline bcl-2 & 7 & 19 & 7 & 2 \\
\hline CD57 & 12 & 23 & 0 & 0 \\
\hline CD61 & 17 & 18 & 0 & 0 \\
\hline
\end{tabular}

Values are numbers of cases reactive

Number of cells reactive: 0 , none; + , up to $10 \%$ of bone marrow cells;,$++ 10-50 \%$ of blast cells; +++ , more than $50 \%$ (usually $100 \%)$ of blast cells.

Table 3 Immunoreactivity of blast cells according to acute lymphoblastic leukaemia ( $A L L$ ) subtype

\begin{tabular}{lllll}
\hline Antibody against & $\begin{array}{l}c-A L L \\
(n=23)\end{array}$ & $\begin{array}{l}T-A L L \\
(n=8)\end{array}$ & $\begin{array}{l}B-A L L \\
(n=2)\end{array}$ & $\begin{array}{l}u-A L L \\
(n=2)\end{array}$ \\
\hline CD10 & 23 & 1 & 0 & 0 \\
CD43 & 20 & 7 & 2 & 2 \\
CD99 & 19 & 8 & 0 & 2 \\
CD45RB & 17 & 4 & 2 & 1 \\
TdT & 18 & 5 & 0 & 1 \\
CD79a & 13 & 0 & 2 & 0 \\
CD34 & 11 & 0 & 0 & 1 \\
CD21 & 9 & 3 & 0 & 0 \\
CD20 & 6 & 0 & 2 & 1 \\
bc1-2 & 7 & 2 & 0 & 0 \\
BF1 & 4 & 6 & 0 & 0 \\
MB1/CD45RA & 2 & 1 & 0 & 1 \\
CD45R & 2 & 1 & 0 & 0 \\
LN3 & 2 & 0 & 0 & 0 \\
CD45R0 & 2 & 5 & 0 & 0 \\
MT2/CD45RA & 1 & 0 & 0 & 1 \\
CD3 & 1 & 3 & 0 & 0 \\
OPD4 & 1 & 1 & 0 & 0 \\
$\alpha$ F1 & 1 & 0 & 0 & 0 \\
\hline
\end{tabular}

Values are numbers of cases reactive.

B, B cell; c, common; T, T cell; u, unclassified.

AML by the application of antibodies against TdT, MPO, and lysozyme.

Currently employed systems for the classification of acute leukaemias are based mainly on cytomorphological, enzyme-cytochemical and immunocytological findings in blood and bone marrow smears. When bone marrow aspiration is unsuccessful, the clinician has to rely on a paraffin embedded bone marrow trephine biopsy specimen for diagnosis. The value of antibodies that can be used on routinely processed tissue for the subtyping of acute leukaemia has been assessed in various studies. ${ }^{17-10}$ Chuang and $\mathrm{Li}^{10}$ suggested a panel of antibodies against MPO, CD79a, CD20, and CD3 for 
Table 4 Immunostaining of the blast cells in the individual cases. Aberrant antigens are underlined

\begin{tabular}{|c|c|c|}
\hline Diagnosis & \multicolumn{2}{|c|}{ Immunophenotype of blast cells } \\
\hline c-ALL & $\begin{array}{l}1 \\
2 \\
3 \\
4 \\
5 \\
6 \\
7 \\
8 \\
9 \\
10 \\
11 \\
12 \\
13 \\
14 \\
15 \\
16 \\
17 \\
18 \\
19 \\
20 \\
21 \\
22 \\
23\end{array}$ & 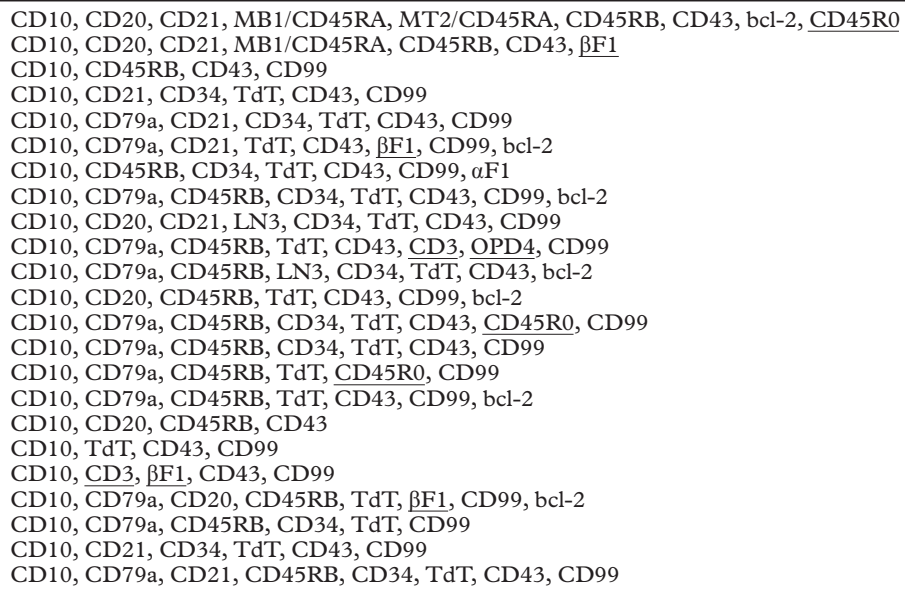 \\
\hline T-ALL & $\begin{array}{l}1 \\
2 \\
3 \\
4 \\
5 \\
6 \\
7 \\
8\end{array}$ & 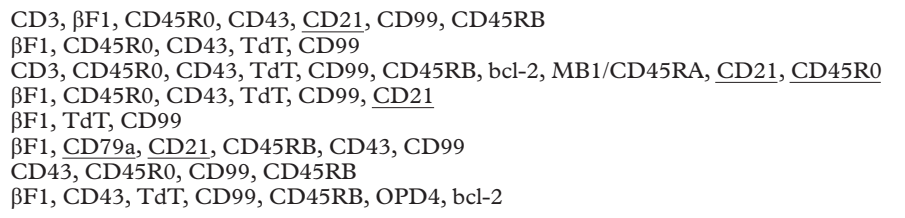 \\
\hline B-ALL & $\begin{array}{l}1 \\
2\end{array}$ & $\begin{array}{l}\text { CD79a, CD20, CD } 45 R B, C D 43, \\
\text { CD79a, CD20, CD } 45 R B, C D 43\end{array}$ \\
\hline $\mathrm{u}-\mathrm{ALL}$ & & $\begin{array}{l}\text { CD } 34, \text { CD } 43, \text { MT2/CD45RA, CD20, MB1/CD } 45 R A, C D 45 R B, C D 99 \\
\text { TdT, CD } 43, \text { CD } 99\end{array}$ \\
\hline Mixed acute leukaemia & $\begin{array}{l}1 \\
2\end{array}$ & $\begin{array}{l}\text { MP0, CD20, } \beta F 1, \text { CD } 43 \\
\text { MP0, TdT, CD43, CD45RB, CD } 99\end{array}$ \\
\hline AML-M1 & $\begin{array}{l}1 \\
2\end{array}$ & $\begin{array}{l}\text { MP0, CD } 34, \mathrm{CD} 43 \\
\text { MP0, CD } 34, \mathrm{CD} 45 \mathrm{RB}\end{array}$ \\
\hline AML-M4 & $\begin{array}{l}1 \\
2\end{array}$ & $\begin{array}{l}\text { Lysozyme, MP0, CD 43, CD 45RB } \\
\text { Lysozyme, MP0, CD 43, CD45RB }\end{array}$ \\
\hline AML-M5a & 1 & Lysozyme, CD45RB \\
\hline
\end{tabular}

the immunohistochemical typing of most cases of acute leukaemia.

Our study, unlike others, included only cases that had been diagnosed as ALL on the basis of blood and bone marrow smears. In addition, we were also able to apply a broader panel of antibodies against haemopoietic antigens, including CD10 and TdT, as more antibodies for use on paraffin embedded tissue have recently become available.

Our findings are generally consistent with those of other studies performed on routinely processed bone marrow biopsy specimens containing infiltrates of ALL, in that it was also found that lymphoid blast cells show marked heterogeneity. ${ }^{1-10}$ Like Chuang and $\mathrm{Li}$, we found that antibodies against MPO, CD79a, and CD20 are very useful for the classification of acute leukaemia. However, in contrast to studies in which anti-CD3 proved to be the most sensitive $\mathrm{T}$ cell marker, ${ }^{9}{ }^{10}$ we found $\beta \mathrm{F} 1$ to be the most reliable and sensitive antibody for the diagnosis of T-ALL.

By using antibodies against MPO and lysozyme, we showed that seven of the cases originally diagnosed as ALL were in fact biphenotypic or mixed acute leukaemias, or showed clear signs of myeloid or myelomonocytic differentiation. MPO and lysozyme are highly specific markers for myeloblasts and monoblasts, respectively. ${ }^{5}{ }^{16}$
The haemopoietic stem cell associated antigen CD34 is expressed by lymphoid and myeloid progenitor cells and blast cells of both ALL and AML. ${ }^{17}{ }^{18}$ The antibody anti-CD34 cannot therefore be used to determine the cell lineage, but may be useful for the differentiation of acute leukaemia from high grade non-Hodgkin lymphoma. ${ }^{19}$ However, TdT is regarded as a highly sensitive marker of immature lymphoid cells, its localisation producing a nuclear staining pattern. An antibody against $\mathrm{TdT}$ has been developed for use on routinely processed bone marrow biopsy specimens. ${ }^{6}$ Of the 35 cases of ALL in our study, 13 expressed CD34 and 25 expressed TdT.

We tested a broad panel of antibodies suitable for use on routinely processed tissue to determine their value in the subtyping of ALL, and found the antibodies anti-CD10, antiCD79a, anti-CD20, and $\beta F 1$ to be of great diagnostic value. All of the 23 cases of c-ALL in our study showed immunoreactivity with a newly developed antibody that detects CD10 in paraffin sections. Immunoreactivity for CD10 was also detected in four of the seven initially unclassified cases, which could then be reclassified as c-ALL. CD79a and CD20 are both specific $B$ cell antigens that are expressed on normal, reactive, and neoplastic B cells. ${ }^{20-25}$ Both the cases of B-ALL but none of the cases of T-ALL were found to express these antigens. 
Of the eight $T$ cell antibodies applied, $\beta \mathrm{F} 1$ proved to be the most sensitive for the diagnosis of T-ALL, staining six of the eight cases. The other $\mathrm{T}$ cell specific antibodies, such as anti-CD 3 and $\alpha \mathrm{F} 1$, were found to be much less sensitive, anti-CD3 staining only two cases and $\alpha \mathrm{F} 1$ none.

\section{CONCLUSIONS}

In summary, we conclude that the subtyping of ALL is usually possible in routinely processed bone marrow trephine biopsy specimens, and we suggest a panel of antibodies against TdT, CD34, MPO, lysozyme, CD10, CD79a, and CD20, and the antibody $\beta F 1$ as a minimum for subtyping acute leukaemia. However, the combined evaluation of both bone marrow biopsy specimens and blood and bone marrow smears by enzyme-cytochemical and immunocytological techniques still appears to represent the best approach for the rapid subtyping of cases of acute leukaemia.

We thank Ms H Ableiter for excellent technical assistance, Pro Dr M R Clemens, Dr A Eichstaedt-Mohn and Dr R Waldmann for providing the clinical diagnoses, and Dr M Ruck for help in preparation of the manuscript. The study was supported by a grant from the Hertie Foundation. Dako Diagnostika (Hamburg) contributed towards the cost of the colour illustrations.

1 Perkins SL, Kjeldsberg CR. Immunophenotyping of lymphomas and leukemias in paraffin-embedded tissues. $A m \mathcal{F}$ Clin Pathol 1993;99:362-73.

2 Picker LJ, Weiss LM, Medeiros LJ, et al. Immunophenotypic criteria for the diagnosis of non-Hodgkin's lymphoma. Am f Pathol 1987;128:181-201.

3 Ngan BY, Picker LJ, Medeiros LJ, et al. Immunophenotypic diagnosis of non-Hodgkin's lymphoma in paraffin sections: diagnosis of non-Hodgkin's lymphoma in paraffin sections: coexpression of L60 (Leu22) and L26 antigens correlates with malign

4 Elghetany MT, Kurec AS, Schuehler K, et al. Immunophenotyping of non-Hodgkin's lymphoma in paraffinembedded tissue sections. A comparison with genotypic analysis. Am f Clin Pathol 1991;95:517-25.

5 Davey FR, Elghetany MT, Kurec AS. Immunophenotyping of hematologic neoplasms in paraffin-embedded tissue sections. Am ₹ Clin Pathol 1990;93:S17-26.

6 Soslow RA, Bhargava V, Warnke RA. MIC2, TdT, bcl-2, and CD34 expression in paraffin-embedded high-grade lymphoma/acute lymphoblastic leukemia distinguishes between distinct clinicopathologic entities. Hum Pathol 1997;28:1158-65

7 Kurec AS, Cruz VE, Barrett D, et al. Immunophenotyping of acute leukemias using paraffin-embedded tissue sections. Am ₹ Clin Pathol 1990;93:502-9.
8 Horny H-P, Wehrmann M, Steinke B, et al. Assessment of the value of immunohistochemistry in the subtyping of acute leukemia on routinely processed bone marrow biopsy specimens with particular reference to macrophageassociated antibodies. Hum Pathol 1994;25:810-14.

9 Rousselet MC, Laniece A, Gardais J, et al. Immunohistochemical characterization of acute leukemia. Study of 31 bone marrow biopsies. Ann Pathol 1995;15:119-26.

10 Chuang Shih-Sung, Li Chin-Yang. Useful panel of antibodies for the classification of acute leukemia by immunohistochemical methods in bone marrow trephine biopsy specimens. Am f Clin Pathol 1997;107:410-18.

11 Orazi A, Cattoretti G, John K, et al. Terminal deoxynucleotidyl transferase staining of malignant lymphomas in paraffin sections. Mod Pathol 1994;7:582-6.

12 Scheuermann RH, Raolla E. CD10 antigen in leukemia and lymphoma diagnosis and immunotherapy. Leuk Lymphoma 1995;18:385-97.

13 Horny H-P, Kaiserling E. Lymphoid cells and tissue mast cells of bone marrow lesions in systemic mastocytosis: a histological and immunohistological study. $\mathrm{Br} \mathcal{F}$ Haematol 1998;69:449-55.

14 Horny H-P, Engst U, Walz RS, et al. In situ immunophenotyping of lymphocytes in human bone marrow: an immunohistochemical study. Br f Haematol 1989;71:31321 .

15 Hsu S, Raine L, Fanger H. Use of avidin-biotin-peroxidase complex (ABC) in immunoperoxidase techniques: a comparison between $\mathrm{ABC}$ and unlabeled antibody (PAP) procedures. $\mathcal{F}$ Histochem Cytochem 1981;29:577-80

16 Pinkus GS, Pinkus JL. Myeloperoxidase: a specific marker or myeloid cells in paraffin sections. Mod Pathol 1991;4: 733-41.

17 Silvestri F, Banavali S, Baccarani M, et al. The CD34 haemopoietic progenitor cell associated antigen: biology

18 Majdic O, Stöckl J, Pickl W. Signaling and induction of enhanced cytoadhesiveness via the haematopoietic proenhanced cytoadhesiveness via the haematopoietic pro-
genitor cell surface molecule CD 34 . Blood 1994;83:122634 .

19 Horny H-P, Wehrmann M, Schlicker HUH, et al. QBEND10 for the diagnosis of myelodysplastic syndromes in routinely-processed bone marrow biopsy specimens. $\mathcal{F}$ Clin Pathol 1995;48:291-4.

20 Cartun RW, Coles FB, Pastuszak WT. Utilization of monoclonal antibody L26 in the identification and confirmation of B-cell lymphomas. Am F Pathol 1987;129:415-21.

21 Takami T, Qi C, Yamada T. Reactivity and specificity of L26 (pan-B-cell $\mathrm{mAb}$ ) on 322 cases of fresh and paraffinembedded lymphoproliferative diseases. In: Knapp W, ed. Abstracts from 4th International Conference on Human Leucocyte Differentiation Antigens, Vienna, 21-25 Feb 1989. Copenhagen: Munksgaard, 1989:134-6.

22 Clark JR, Williams ME, Swerdlow SH. Detection of B- and T-cells in paraffin-embedded tissue sections. Diagnostic utility of commercially obtained 4KB5 and UCHL-1. Am $\mathcal{F}$ Clin Pathol 1990;93:58-69.

23 Buccheri V, Mihaljevic B, Matutes E, et al. mb-1: a new marker for B-lineage lymphoblastic leukemia. Blood 1993;82:853-7.

24 Verschuren MCM, Comans-Bitter WM, Kapteijn CAC, et al. Transcription and protein expression of mb-1 and B29 genes in human hematopoetic malignancies and cell lines. Leukemia 1993;7:1939-47.

25 Mason DY, Cordell JL, Brown MH, et al. CD79a: a novel marker for B-cell neoplasms in routinely-processed tissue samples. Blood 1995;86:1453-9. 